\title{
Evaluation of Enzyme Expression in a Macrophytic Treated Crude Oil Soil Habitat: Implication for Enhanced Phytoremediation Potential Using Transgenic Botanicals
}

\author{
${ }^{1}$ Nsirim L. Edwin-Wosu and ${ }^{2}$ Ani E. Nkang \\ ${ }^{1}$ Department of Plant Science and Biotechnology, Faculty of Biological Science, College of Natural and \\ Applied Sciences, University of Port Harcourt, Choba, PMB 5323, Rivers State, Nigeria \\ ${ }^{2}$ Department of Botany, University of Calabar, Cross River State, Nigeria
}

\begin{abstract}
Background: Several studies have demonstrated the success of phytoremediation and its advantages over conventional physical and biochemical (even engineered transgenics) methods, resulting in its use on many contaminated sites. A direct method for enhancing the effectiveness of phytoremediation is to over express the genes in transgenic plants that are involved in metabolism, uptake and/or transport of specific pollutants. Objective: A screen-house ecological study was carried out to evaluate the remediation potentials of three species of the Fabaceae Family (Peltophorum pterocarpum, Leucaena leucocephala and Crotolaria retusa) for cleaning up soils contaminated with crude oil petroleum hydrocarbons. Result: Enzymatic analysis and hydrocarbon index assessment of the species and the vegetated and non-vegetated soils showed that $P$. pterocarpum recorded significant $(\mathrm{p}<0.05)$ performance over C. retusa and L. leucocephala in the uptake of hydrocarbons (oil and Grease (OG), Total Hydrocarbon Content (THC), organic carbon and organic matter content]. Results showed significant $(\mathrm{p}<0.05)$ reduction in enzyme expression and soil hydrocarbon index. C. retusa recorded significant $(\mathrm{p}<0.05)$ increase over $P$. pterocarpum and L. leucocephala in enzyme expression and reduction in foliar hydrocarbon index, with significant $(\mathrm{p}<0.05)$ increase in soil hydrocarbon index. Conclusion: Crotolaria retusa can thus be recommended as an integral component of any bioremediation technology package for hydrocarbon polluted terrestrial environment and by it transgenic enhancement of indigenous enzymes.
\end{abstract}

Key words: Detoxification, Peltophorum pterocarpum, Leucaena leucocephala, Crotolaria retusa peroxidase, polyphenoloxidase

Insight Ecology 4 (1): 13-23, 2015

\section{INTRODUCTION}

The issue of pollution with organic and inorganic pollutants, whether point or non point sources, on any environmental media (air, land or aquatic) is a recurrent global problem. The approach to providing solution to such pollution incidents is very demanding. Conventional physical, chemical and biological methods for remediation of contaminated sites have attendant inadequacies and pitfalls. Therefore, the development of innovative remediation technologies for the decontamination of impacted sites is of paramount importance and calls for processes that are economically

Corresponding Author: Nsirim L. Edwin-Wosu, Department of Plant Science and Biotechnology, Faculty of Biological Science, College of Natural and Applied Sciences, University of Port Harcourt, Choba, PMB 5323, Rivers State, Nigeria sound and environmentally friendly. Plants are sedentary in nature and have evolved diverse strategies for dealing with toxic organic and inorganic compounds in their environment $t^{1,2}$. Plants can be seen as natural, solar-powered pump-and-storage systems for cleaning up contaminated environments, leading to the concept of phytoremediation ${ }^{3}$. First developed for the removal of heavy metals from soil, the technology has since proven to be efficient for the treatment of organic compounds, including chlorinated solvents, polyaromatic hydrocarbons and explosives ${ }^{1,3}$. Phytoremediation has long been recognized as a cost effective method for the decontamination of soil and water resources ${ }^{4,5}$. It is a process by which plants detoxify soils, sediments and aquatic sites contaminated with organic and inorganic pollutants $^{1}$ and it has proven to be a sustainable and 
effective technology ${ }^{2}$. It is time consuming but much less expensive and destructive than physical or chemical remediation. Phytoremediation is best suited to sites that are contaminated to a depth of less than $5 \mathrm{~m}$ and those containing moderately hydrophobic pollutants $(\log \mathrm{K}=0.5-3)$, short chain aliphatic chemicals or excess nutrients ${ }^{6}$. The process can be used to remove hydrocarbons from water and soil because most hydrocarbons are moderately hydrophobic. Some plants can remove organic pollutants, including hydrocarbons by taking them up from the environment through the roots and leaves. The absorbed pollutants are bio-chemically converted into non-toxic metabolites that accumulate in the plants tissues.

Several studies have demonstrated the success of phytoremediation and its advantages over conventional physical and biochemical (even engineered transgenics) methods, resulting in its use on many contaminated sites in laboratory and pilot field scale projects. Despite these promising findings and a certain degree of public acceptance the method still lacks wide application, as the detoxification of accumulated organic and inorganic pollutants by plants is often slow, leading to the accumulation of toxic compounds that could be released into the environment and more so into food chains ${ }^{7-14}$.

The question of how to dispose of plants that accumulate organic pollutants is an issue of serious concern. Field trials have suggested that the rate of contaminant removal using conventional plants is inadequate ${ }^{15}$. Thus for more effective metabolism of organic pollutants, transgenic plants have been developed which are endowed with genes from organisms that can degrade chemical pollutants ${ }^{16,17}$. A direct method for enhancing the effectiveness of phytoremediation is to over express the genes in transgenic plants that are involved in metabolism, uptake and/or transport of specific pollutants ${ }^{12,17}$.

Phytoremediation involves enzymatic degradation processes that potentially lead to contaminant detoxification $^{3}$. Pollutant-degrading enzymes (e.g. peroxidases, polyphenol oxidases) in plants probably originated from natural defense systems against a variety of allelochemicals released by competing organisms, including microbes, insects and other plants, Peroxidases are widely distributed in living organisms including plants. Plant peroxidases are localized mainly in cell wall and in vacuole and are associated with non-specific oxidative polymerization of phenolic units in the cell wall to make lignin. Plant roots exude high concentrations of peroxidases into soil, particularly in response to chemical stress. Peroxidases have been implicated in a wide range of physiological processes such as auxin metabolism, lignin and suberin formation, cross- linking of cell wall components and defense against pathogens ${ }^{19,20}$. Peroxidases have also been implicated in the accumulation of heavy metals by some plant species and the degradation of toxic molecules and pesticides $^{21,22}$. Polyphenol oxidases are oxidoreductases that catalyse oxidation of phenolic compounds and widely distributed with extracellular localization in plants. Depending on the source organism, physiological and pathological conditions, their roles include cross-linking of monomers, degradation of polymers and ring cleavage of aromatic compounds ${ }^{23}$. Their release also facilitates the oxidative degradation of certain soil constituents ${ }^{24}$.

Enzymatic transformation in plants concerns mainly organic pollutants. In this process, plants take organic pollutants and subsequently metabolize or transform them into less toxic metabolites. Once taken up and translocated, the organic chemicals generally undergo three transformation stages: (i) chemical modification (oxidations, reductions, hydrolysis), (ii) conjugation (with glutathione, sugars, amino acids) and (iii) sequestration or compartmentalization (conjugants are converted to other conjugates and deposited in plant vacuoles or bound to the cell wall and lignin $)^{25}$.

Transgenic plants for high-efficiency phytoremediation can be produced when genes involved in all three phases of organic pollutant metabolism are properly incorporated into the host plant. If plants are able to degrade xenobiotics to non-toxic metabolites or completely mineralized into carbon dioxide, nitrate, chlorine etc., There is no apprehension over hazardous waste management strategies for disposing of such harvested plants. This work reports on the ecological potentials of $P$. pterocarpum, $L$. leucocephala and $C$. retusa for enhanced degradation and mineralization of hydrocarbon contaminants and as Demonstrated Phytoremediation Macrophytes (DPM), Suspected Phytoremediation Macrophytes (SPM) or Hydrocarbon-Tolerant Macrophytes (HTM) ${ }^{26}$.

\section{MATERIALS AND METHODS}

Sources of materials: On the basis of the Stewarte $e$ t $a .^{27}$ and Song et al. ${ }^{28}$ approach, replicates of top loam soil $(20 \mathrm{~kg})$ were collected in bulk within the standardized 0-15 cm soil layer from a fallowed garden land of the Faculty of Agriculture, University of Calabar, Cross River State, Nigeria. The seeds of $P$. pterocarpum were obtained from one of the green belt formations of the University of Port Harcourt, Rivers State, Nigeria. The seeds of L. leucocephala and C. retusa were obtained from the wild in a dump site in Port Harcourt and authenticated in the University of Port Harcourt 
Herbarium. The crude oil blend "Bonny light" used was obtained from the Port Harcourt Refinery Alesa/Eleme, Rivers State. All chemical reagents, glass wares and equipment used in this study were of analytical grade and were purchased from Welly International Company, Port Harcourt, Nigeria (Scientific/Hospital and Chemical suppliers) and the Department of Botany, University of Calabar, Nigeria.

Experimental design and pollution of the study site with crude oil: The "nested design" of Akindele ${ }^{29}$ was adopted in this study using a split-split (double split) plot design in which the nested analysis of variance (PROC. ANOVA) procedure ${ }^{30}$ was carried out on series of experimental plots. Three different species of plants were employed in the remediation of different crude oil polluted sites. The pollutant was applied using a measuring cylinder. The pollution was done in four concentrations, by volume $(\mathrm{mL})$ or weight (\%) respectively, of $0(0 \%), 75(0.4 \%), 150(0.8 \%)$ and 300 $(1.5 \%)$ per $1,809 \mathrm{~cm}^{2}$ of soil surface area. At each level of pollution treatments were performed and replicated five times. Data on enzyme expression of the plant species in relation to organic uptake and mineralization of crude oil in polluted sites were obtained. Differences in species performance and soil treatments were tested by treatment interaction and treatment by levels interaction as the error terms.

Habitat reclamation treatments: Each of the three levels of pollution and the controls were subjected to habitat reclamation using three members of the Fabaceae family ( $P$. pterocarpum, $L$. leucocephala and $C$ retusa). Seedlings of the selected plants were raised in nurseries at the Faculty of Agriculture, University of Calabar. Following germination and seedling growth, healthy 14 day old seedlings were selected for analysis and represented the pre-pollution samples. Healthy 14 day old seedlings of the three species were also transplanted from the nurseries onto the control and polluted soils. Some plants were harvested 7 days after transplantation and represented the post-pollution samples. Subsequently, plants were allowed to grow on the control and treated soils for 10 months before final harvesting, representing the post-phytoremediation samples. Foliar enzyme expressions of the plants were assessed at each harvest interval and used as a measure of their level of tolerance in the polluted environment. Analysis of enzyme, Total Hydrocarbon Content (THC), oil and grease, total organic carbon and matter was done as described below.
Enzyme assay and hydrocarbon index analysis of the remediation species: An extraction buffer of $150 \mathrm{~mL}$ was prepared for use. The $20 \mathrm{mM}$ mixed phosphate buffer consisted of a monobasic potassium phosphate salt $\left(\mathrm{KH}_{2} \mathrm{PO}_{4}\right)$ and dibasic potassium phosphate salt $\left(\mathrm{K}_{2} \mathrm{HPO}_{4}\right)$ containing $2 \%$ of the Phenolic Adsorbent Polyvinyl Polypyrollidone (PVPP). The $\mathrm{pH}$ was adjusted to 7.1 at room temperature $\left(30^{\circ} \mathrm{C}\right)$ using $1 \mathrm{M} \mathrm{KOH}$. This extraction buffer was stored at $4^{\circ} \mathrm{C}$. A known quantity of fresh leaf $(0.5 \mathrm{~g})$ sample was ground in $10 \mathrm{~mL}$ of the extraction buffer using a pestle and mortar. The ground tissue was filtered through cheese cloth and the filtrate centrifuged at $4000 \mathrm{rpm}$ for 30 min to obtain a clear supernatant. The supernatant fractions were stored on ice and used as crude enzyme source for assaying for peroxidase (POD) and polyphenoloxidase (PPO) activity ${ }^{31}$.

Peroxidase assay and activity was determined based on Nkang ${ }^{31}$ and Putter ${ }^{32}$ methods while Polyphenoloxidase assay and activity was by adopting the $\mathrm{Kahn}^{33}$ and Garcia-Carmora, ${ }^{34}$ methods.

Determination of Total Hydrocarbon Content (THC): The photometric method of the American Petroleum Institute was adopted for the determination of THC in the plant species and soils ${ }^{35}$. The oil and grease content (OG) was determined spectrophotometrically according to the toluene extraction method adopted by Odu et al. ${ }^{36}$. The content was calculated by reference to a calibration curve using toluene as standard.

Total Organic Carbon (TOC): This was estimated using the Walkley and Black ${ }^{37}$ method as modified by Nelson and Somners ${ }^{38}$ for both soil and plant samples, following a complete oxidation from the heat of solution and external heating of sulphuric acid $\left(\mathrm{H}_{2} \mathrm{SO}_{4}\right)$ and aqueous potassium dichromate $\left(\mathrm{K}_{2} \mathrm{Cr}_{2} \mathrm{O}_{7}\right)$ mixture. This was determined using the designated formula.

Data analysis by SAS package: The remediation performance was estimated using the Statistical Analysis System (SAS) PROC. NLIN procedure ${ }^{30}$. Data were then analysed as a split-split (double-split) plot design with 10 replicates using the Analysis of Variance (PROC ANOVA) procedures ${ }^{30}$. Where significant differences were observed, means were separated according to the procedures of the Duncan's New Multiple Range Test (DNMRT) at LSD $\mathrm{p}<0.05$.

\section{RESULTS}

Results of enzyme activity in the three plant species are shown in Table 1. In the pre-pollution phase, 


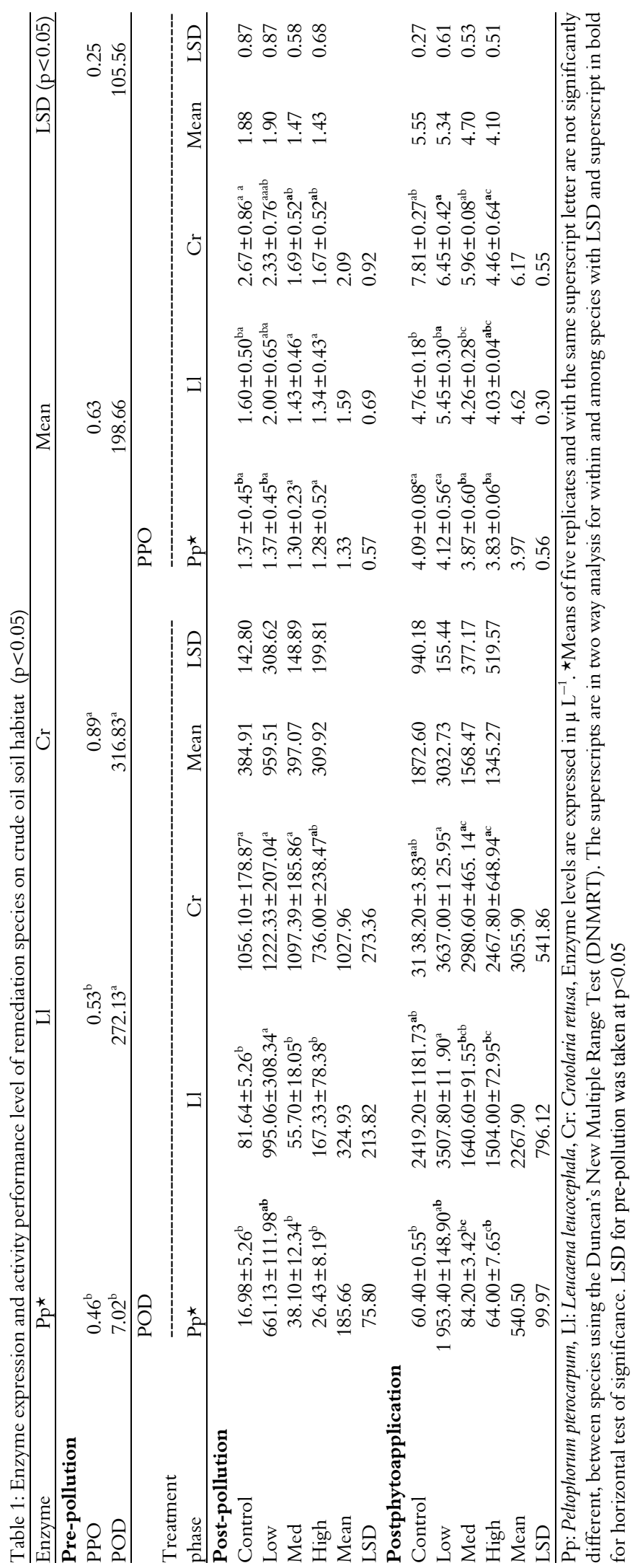


expression of PPO and POD activities were significantly different $(\mathrm{p}<0.05)$ in $C$. retusa while $P$. pterocarpum was significantly $(\mathrm{p}<0.05)$ lower in POD expression level. In the post-pollution phase, $P$. pterocarpum recorded decrease in POD as pollution levels increased but with higher values than control. There was low POD expression in $C$. retusa at high crude oil pollution levels relative to the control but non-significantly different $(\mathrm{p}<0.05)$. L. leucocephala recorded high significantly different $(\mathrm{p}<0.05)$ POD expression at low pollution levels but non-significantly lower at medium pollution level. Generally, there was reduction in POD expressions in all species as pollution levels increased.

In the post-phytoapplication phase, a similar trend of enzyme expression was indicated in the species. In the remediated habitat there was non-significant $(\mathrm{p}<0.05)$ increase in foliar POD expression in all the species at low pollution levels. Subsequently, POD expressions in all the species decreased as pollution levels increased. However, at medium and high pollution levels foliar POD expressions in L. leucocephala and C. retusa were lower than in control plants. Among the species, there was non-significant difference $(p<0.05)$ but with higher enzyme expression in C. retusa. The foliar PPO enzyme expression in the remediating species did not differ significantly $(p<0.05)$ within pollution levels in all the species. At low pollution levels, PPO expression was higher than in control plants except in C. retusa. Subsequently, PPO expression in all species declined as pollution levels increased. Among the species a similar trend of non-significant difference $(\mathrm{p}<0.05)$ was recorded but with higher enzyme expression in C. retusa. The carbon content of remediating plants of P. pterocarpum, L. leucocephala and C. retusa in the crude oil polluted soil habitat is shown in Table 2. Within species L. leucocephala and C. retusa recorded significant differences $(p<0.05)$ at control level. There was non-significant decrease in TOC content of all species as pollution levels increased. However, higher TOC content than in controls was recorded in L. leucocephala at all pollution levels and at low and medium pollution levels in C. retusa.

The total organic matter content within species showed non-significant difference $(p<0.05)$ except in $L$. leucocephala and $C$. retusa at control level. Non-significant reduction in TOM in P. pterocarpum was observed with increasing pollution levels. However, in L. leucocephala and C. retusa, TOM of plants was higher than in the control at low and medium pollution levels. $P$. pterocarpum among the species had significant $(\mathrm{p}<0.05)$ higher levels in control plants and generally higher content of TOM.

Oil and grease content in all the species remained relatively constant or decreased with increased pollution levels. Within species, C. retusa and L. leucocephala recorded significantly $(\mathrm{p}<0.05)$ low foliar oil and grease content at high pollution levels. Species in polluted soil recorded higher contents than in control plants. $P$. pterocarpum and C. retusa had higher contents at low

Table 2: Hydrocarbon indices of remediating plant species on crude oil polluted soils

\begin{tabular}{|c|c|c|c|c|c|}
\hline Hydrocarbon index & $\mathrm{Pp}^{\star}$ & $\mathrm{Ll}$ & $\mathrm{Cr}$ & Mean & $\operatorname{LSD}(p=0.05)$ \\
\hline \multicolumn{6}{|c|}{ Total organic Carbon } \\
\hline Control & $2.61 \pm 0.31^{\mathrm{a}}$ & $1.12 \pm 0.43^{\mathrm{b}}$ & $1.45 \pm 0.42^{\mathrm{b}}$ & 1.73 & 0.54 \\
\hline Low & $2.08 \pm 0.70^{\mathrm{a}}$ & $1.81 \pm 0.36^{\mathrm{a}}$ & $1.99 \pm 0.54^{\mathrm{a}}$ & 1.94 & 0.76 \\
\hline Medium & $1.92 \pm 0.18^{\mathrm{a}}$ & $1.81 \pm 0.09^{\mathrm{a}}$ & $1.81 \pm 0.28^{\mathrm{a}}$ & 1.85 & 0.27 \\
\hline High & $1.49 \pm 0.33^{\mathrm{a}}$ & $1.55 \pm 0.25^{\mathrm{a}}$ & $1.24 \pm 0.10^{\mathrm{a}}$ & 1.43 & 0.34 \\
\hline \multicolumn{6}{|c|}{ Total organic Matter } \\
\hline Control & $4.51 \pm 0.53^{\mathrm{a}}$ & $1.94 \pm 0.75^{\mathrm{b}}$ & $2.51 \pm 0.73^{b}$ & 2.99 & 0.93 \\
\hline Low & $3.47 \pm 1.21^{\mathrm{a}}$ & $3.14 \pm 0.63^{\mathrm{a}}$ & $3.44 \pm 0.93^{\mathrm{a}}$ & 3.35 & 1.31 \\
\hline Medium & $3.32 \pm 0.31^{\mathrm{a}}$ & $3.12 \pm 0.16^{\mathrm{a}}$ & $3.13 \pm 0.48^{\mathrm{a}}$ & 3.19 & 0.47 \\
\hline High & $2.58 \pm 0.56^{\mathrm{a}}$ & $2.60 \pm 0.43^{\mathrm{a}}$ & $2.14 \pm 0.17^{\mathrm{a}}$ & 2.44 & 0.58 \\
\hline \multicolumn{6}{|l|}{ Oil and grease } \\
\hline Control & $64.26 \pm 0.43^{\mathrm{a}}$ & $64.06 \pm 0.72^{\mathrm{a}}$ & $62.42 \pm 1.49^{\mathrm{b}}$ & 63.58 & 1.36 \\
\hline Low & $64.88 \pm 0.75^{a}$ & $63.00 \pm 0.37^{\mathrm{b}}$ & $63.58 \pm 0.55^{\mathrm{b}}$ & 63.82 & 0.80 \\
\hline Medium & $63.76 \pm 0.33^{\mathrm{a}}$ & $61.12 \pm 0.73^{c}$ & $62.62 \pm 0.49^{\mathrm{b}}$ & 62.50 & 0.75 \\
\hline High & $63.65 \pm 2.31^{\mathrm{a}}$ & $60.01 \pm 4.05^{\mathrm{a}}$ & $60.96 \pm 0.36^{\mathrm{a}}$ & 61.54 & 3.72 \\
\hline \multicolumn{6}{|l|}{ THC } \\
\hline Control & $61.11 \pm 2.66^{\mathrm{a}}$ & $55.72 \pm 2.08^{\mathrm{b}}$ & $55.42 \pm 1.72^{\mathrm{b}}$ & 57.42 & 3.02 \\
\hline Low & $61.90 \pm 0.79^{a}$ & $61.67 \pm 0.48^{\mathrm{a}}$ & $60.45 \pm 1.94^{\mathrm{a}}$ & 61.34 & 1.50 \\
\hline Medium & $60.68 \pm 1.65^{a}$ & $53.48 \pm 0.48^{c}$ & $59.63 \pm 0.89^{\mathrm{b}}$ & 57.73 & 1.54 \\
\hline High & $54.19 \pm 1.31^{\mathrm{a}}$ & $52.95 \pm 2.83^{\mathrm{a}}$ & $55.89 \pm 5.03^{\mathrm{a}}$ & 54.34 & 4.71 \\
\hline
\end{tabular}

Pp: Peltophorum pterocarpum, Ll: Leucaena leucocephala, Cr: Crotolaria retusa. ${ }^{\star}$ Means of five replicates and with the same superscript letter are not significantly different, between species or treatment using the Duncan's New Multiple Range Test (DNMRT), a, b, c: Degree of significance 
to medium pollution levels. Among the species $P$. pterocarpum recorded a higher oil and grease content that was significantly different $(\mathrm{p}<0.05)$ at low and medium pollution levels.

The total hydrocarbon concentration within species showed significant difference $(\mathrm{p}<0.05)$ in L. leucocephala at medium crude pollution levels. THC content in all the species remained relatively constant or decreased with increased pollution levels. Higher THC content than in the control species was recorded at low pollution levels in P. pterocarpum and L. leucocephala while C. retusa recorded higher content at all levels of pollution than the control. Among the species P. pterocarpum recorded higher THC content and this was significantly different $(\mathrm{p}<0.05)$ at medium pollution levels.

The Total Organic Carbon (TOC) of the pre-polluted, post-polluted and post-phytoremediated soil is shown in Tables 3 and 4 . The TOC in the pre-polluted soil was $0.85 \pm 0.13$ and this was significantly different $(p<0.05)$ and lower than in the polluted soils. The TOC values increased markedly in post-pollution soils and recorded $1.61 \pm 0.32,1.75 \pm 1.00$ and $2.20 \pm 0.10$ at 75,100 and $300 \mathrm{~mL}$ pollution levels, respectively. The values were significantly different $(\mathrm{p}<0.05)$ at $1.5 \%$ pollution level.

The TOM in the pre-polluted soil was $1.46 \pm 0.22$ and this was significantly different $(\mathrm{p}<0.05)$ and lower than in the polluted soils. The TOM values increased markedly in post-pollution soils and recorded $2.78 \pm 1.00$, $3.02 \pm 2.00,3.81 \pm 0.69$ at the different pollution levels. The values were significantly different $(\mathrm{p}<0.05)$ at $1.5 \%$ pollution level. There was no significant difference $(\mathrm{p}<0.05)$ in organic matter content within and among species in post-phytoremediated crude oil soils. Values were generally higher than in controls except at the low pollution level in Peltophorum and Leucaena. However, Peltophorum treated soil had a lower content with nonsignificant difference $(\mathrm{p}<0.05)$.

The oil and grease content in the pre-polluted soil was $0.64 \pm 0.10$ and this was significantly different $(p<0.05)$

Table 3: Hydrocarbon indices of pre and post-polluted crude oil contaminated soils

\begin{tabular}{|c|c|c|c|c|c|c|}
\hline \multirow[b]{2}{*}{ Hydrocarbon index } & \multirow[b]{2}{*}{ Pre-pollution } & \multicolumn{3}{|c|}{ Post-pollution } & \multirow[b]{2}{*}{ Mean } & \multirow[b]{2}{*}{$\operatorname{LSD}(p<0.05)$} \\
\hline & & Low & Medium & High & & \\
\hline TOC & $0.85^{\mathrm{c}}$ & $1.61^{\mathrm{b}}$ & $1.75^{\mathrm{b}}$ & $2.20^{\mathrm{a}}$ & 1.60 & 0.40 \\
\hline TOM & $1.46^{\mathrm{c}}$ & $2.78^{\mathrm{b}}$ & $3.02^{\mathrm{b}}$ & $3.81^{\mathrm{a}}$ & 2.77 & 0.70 \\
\hline $\mathrm{O} / \mathrm{G}$ & $0.64^{\mathrm{c}}$ & $2.84^{\mathrm{b}}$ & $5.13^{\mathrm{a}}$ & $6.18^{\mathrm{a}}$ & 3.70 & 1.69 \\
\hline THC & $1.25^{\mathrm{c}}$ & $7.32^{\mathrm{b}}$ & $8.72^{\mathrm{ab}}$ & $10.33^{\mathrm{a}}$ & 6.91 & 2.43 \\
\hline
\end{tabular}

TOC: Total organic carbon, TOM: Total organic matter, O/G: Oil and grease, THC: Total hydrocarbon content

Table 4: Hydrocarbon indices of post-polluted crude oil contaminated soils

\begin{tabular}{|c|c|c|c|c|c|}
\hline Hydrocarbon index & $\mathrm{Pp}^{\star}$ & LI & $\mathrm{Cr}$ & Mean & $\operatorname{LSD}(\mathrm{p}<0.05)$ \\
\hline \multicolumn{6}{|l|}{ Organic carbon } \\
\hline Control & $1.20 \pm 0.17^{\mathrm{a}}$ & $0.95 \pm 0.22^{\mathrm{a}}$ & $1.00 \pm 0.05^{\mathrm{a}}$ & 1.05 & 0.48 \\
\hline Low & $0.73 \pm 0.24^{\mathrm{a}}$ & $1.11 \pm 0.25^{\mathrm{a}}$ & $1.07 \pm 0.39^{\mathrm{a}}$ & 0.97 & 0.42 \\
\hline Medium & $1.21 \pm 0.22^{\mathrm{ab}}$ & $1.60 \pm 0.40^{\mathrm{a}}$ & $1.16 \pm 0.13^{\mathrm{b}}$ & 1.31 & 0.38 \\
\hline High & $1.30 \pm 0.07^{\mathrm{b}}$ & $1.59 \pm 0.30^{\mathrm{a}}$ & $1.43 \pm 0.22^{\mathrm{ab}}$ & 1.44 & 0.27 \\
\hline \multicolumn{6}{|l|}{ Organic matter } \\
\hline Control & $1.64 \pm 0.39^{\mathrm{a}}$ & $2.08 \pm 0.29^{\mathrm{a}}$ & $1.73 \pm 0.91^{\mathrm{a}}$ & 1.82 & 0.82 \\
\hline Low & $1.25 \pm 0.43^{\mathrm{a}}$ & $1.85 \pm 0.68^{\mathrm{a}}$ & $1.93 \pm 0.44^{\mathrm{a}}$ & 1.68 & 0.73 \\
\hline Medium & $2.10 \pm 0.38^{\mathrm{ab}}$ & $2.01 \pm 0.23^{\mathrm{b}}$ & $2.68 \pm 0.69^{a}$ & 2.26 & 0.65 \\
\hline High & $2.25 \pm 0.13^{\mathrm{b}}$ & $2.48 \pm 0.37^{\mathrm{ab}}$ & $2.75 \pm 0.43^{\mathrm{a}}$ & 2.49 & 0.47 \\
\hline \multicolumn{6}{|l|}{ Oil and grease } \\
\hline Control & $0.38 \pm 0.10^{\mathrm{b}}$ & $0.46 \pm 0.08^{\mathrm{ab}}$ & $0.56 \pm 0.14^{\mathrm{a}}$ & 0.47 & 0.15 \\
\hline Low & $1.20 \pm 0.30^{\mathrm{b}}$ & $2.11 \pm 0.33^{\mathrm{a}}$ & $1.34 \pm 0.35^{\mathrm{a}}$ & 1.55 & 0.45 \\
\hline Medium & $2.21 \pm 0.31^{\mathrm{a}}$ & $2.24 \pm 0.22^{\mathrm{a}}$ & $2.34 \pm 0.18^{a}$ & 2.27 & 0.33 \\
\hline High & $2.98 \pm 0.65^{\mathrm{b}}$ & $3.86 \pm 0.25^{\mathrm{a}}$ & $3.54 \pm 0.71^{\mathrm{ab}}$ & 3.46 & 0.80 \\
\hline \multicolumn{6}{|l|}{ THC } \\
\hline Control & $0.98 \pm 0.18^{\mathrm{b}}$ & $1.19 \pm 0.17^{\mathrm{a}}$ & $1.10 \pm 0.04^{\mathrm{ab}}$ & 1.09 & 0.20 \\
\hline Low & $3.17 \pm 0.30^{\mathrm{a}}$ & $3.62 \pm 1.04^{\mathrm{a}}$ & $2.87 \pm 0.51^{a}$ & 3.22 & 0.95 \\
\hline Medium & $4.85 \pm 0.85^{\mathrm{a}}$ & $4.28 \pm 1.00^{\mathrm{a}}$ & $4.96 \pm 0.40^{\mathrm{a}}$ & 4.70 & 0.88 \\
\hline High & $6.86 \pm 0.35^{\mathrm{b}}$ & $7.80 \pm 0.20^{\mathrm{a}}$ & $7.78 \pm 0.48^{\mathrm{a}}$ & 7.48 & 0.50 \\
\hline
\end{tabular}

Pp: Peltophorum pterocarpum, Ll: Leucaena leucocephala, Cr: Crotolaria retusa. ${ }^{\star}$ Means of five replicates and with the same superscript letter are not significantly different, between species or treatment using the Duncan's New Multiple Range Test (DNMRT), a, b, c: Degree of significance 
and lower than in the polluted soils. The oil and grease content increased markedly in post-pollution soils and recorded $3.00 \pm 1.24,5.13 \pm 1.00$ and $6.18 \pm 2.00$ at the different pollution levels. There was no significant difference $(p<0.05)$ in oil and grease content within and among species in post-phytoremediated crude oil contaminated soils. Peltophorum treated soil recorded the least oil and grease content, with significant difference $(\mathrm{p}<0.05)$ at low $(0.4 \%)$ pollution level.

The THC in the pre-polluted soil was 1.25 and this was significantly different $(\mathrm{p}<0.05)$ and lower than in the polluted soils. The THC values increased markedly in post-pollution soils and recorded 7.32, 8.72 and 10.33 at the different pollution levels. The values were significantly different $(\mathrm{p}<0.05)$ at high pollution level. There was no significant difference $(\mathrm{p}<0.05)$ in THC within and among species in post-phytoremediated crude oil contaminated soils. Values were generally higher than in controls, in an increasing order relative to different pollution levels.

\section{DISCUSSION}

There is considerable interest in the use of biocatalysts for bioremediation ${ }^{39}$. There is increased realization of the power of biocatalysts for creating hydrocarbon tolerant and resistant plant species and for the detoxification of soil and water contaminants using phytoremediation $^{40}$. The use of transgenic plants for phytoremediation is critical because plants do not have the ability to completely catabolize toxic compounds that are common in food chains, such as herbicides, pharmaceuticals, petrochemicals, polycyclic aromatic hydrocarbons (PAHs) and polychlorinated biphenyls $(\mathrm{PCBs})^{41,42}$. Since many enzymes have the capability to metabolize these compounds into relatively safe products, they can be employed in the development of transgenic plants for purposes such as crude oil contaminated soil remediation.

There were significant differences within and among the species in enzymic activities and expression in pre-pollution, post-pollution and post-phytoapplication remediation phases. POD and PPO enzyme activities showed varying levels of expression in the species. Foliar POD and PPO enzymic expression among the species was in the order $\mathrm{Cr}>\mathrm{Ll}>\mathrm{Pp}$. Reduction in foliar POD and PPO activities was observed within species as pollution levels increased. Pollutant-degrading enzymes in plants probably originate from natural defense systems against the variety of allelochemicals released by competing organisms, including microbes, insects and other plants ${ }^{18}$ including anthropogenic intentions such as hydrocarbon pollution.
In similar metabolic studies, the ability of plants to take up and metabolize a range of environmentally problematic organic pollutant, including ammonia waste (TNT and GTN), polychlorinated biphenyls (PCBs) and trichloroethylene (TCE) was established through enzyme secretion ${ }^{43,44}$. Plant species have been known for their capacity to release a range of compounds from their roots. Such compounds referred to as phyto-remediation explanta ${ }^{45}$ or botanica explanta ${ }^{46}$ differ considerably in type and rate among such species and are capable of degrading chemical compounds in their immediate vicinity. Such enzyme exudates include laccases, dehalogenases, nitroductases, nitrilases, peroxidases, phosphatase, aromatic dehalogenase and O-demethylase. Peroxidase activity on root surface of Eichhornia crassipes (water hyacinth) have been indicated in polymerized guaiacol $^{47}$, reduced mineralization of naphthalene in soil planted with Chloris gayana (unlike non-vegetated soil, possibly because root enzyme exudates may have placed naphthalene-degrading microbes at a competitive disadvantage $)^{48}$. Tobacco plants containing a human cytochrome P450 2EI enzyme transformed up to 640 times the amount of TCE compound relative to control plants ${ }^{49}$. Polyphenol oxidase in tomato plant increased oxidation rate of soluble phenolic ${ }^{50}$. Laccase, present in Arabidopsis thialiana ${ }^{51}$ helps plants in oxidation of allelopathic flavonoid catechin and detoxify the immediate growth environment ${ }^{52,53}$. These enzymes are capable of transforming organic contaminants by catalyzing chemical reactions in soil.

Foliar organic carbon and organic matter showed non-significant differences in content among the species planted in crude oil remediated soil. The foliar content of organic matter, oil and grease and THC showed increased accumulation in the order $\mathrm{Pp}>\mathrm{Ll}>\mathrm{Cr}$. The post-phytoapplication variation in foliar concentration of oil and grease and THC among the species planted in crude oil remediated soil showed increased accumulation as pollution levels decreased, possibly due to enhanced root formation and enhanced moisture content at low to medium pollution levels. This observation is explained by the fact that plants have the ability to take up and metabolize a range of environmentally problematic organic pollutants ${ }^{44}$.

Carbon and organic matter content of plants varied considerably depending on soil pollution levels. Carbon and organic matter content increased gradually as pollution levels increased in the post-polluted soil habitat as compared to the pre-polluted soil. The pre-pollution soil was significantly lower in carbon and organic matter than the crude oil polluted habitat. This could be due to lack of exogenous source of carbon. 
Phyto-application led to a reduction in carbon and organic matter content, when compared to post-pollution. The content of TOC and TOM in crude oil contaminated soils planted with $P$. pterocarpum, L. lecucocephala and C. retusa was in the order of $\mathrm{Pp}<\mathrm{Cr}<\mathrm{Ll}$ and $P p<L l<C r$, respectively. $P$. pterocarpum had the lowest content. The higher reduction in carbon content in $P$. pterocarpum treated soil is an indication of the species more efficient utilization of carbon than the other species. This enhanced hydrocarbon degradation would lead to the production of carbon, water and carbon dioxide in the presence of phosphorus, nitrogen nutrients and other environmental variables. The carbon becomes incorporated into the plant biomass, thus depleting the carbon and organic matter content of the soil. The reduced expression of enzymic activities in $P$. pterocarpum with enhanced hydrocarbon degradation and reduction in hydrocarbon indices in the soil and associated increase in the aerial parts of the plants is of interest and importance in contaminant remediation. These results might have implications in developing transgenic plants for enhanced peroxidase and polyphenoloxidase activity, stability and expression in phytoremediation.

The pre-pollution oil and grease content in soil was lower than the content under polluted conditions. Oil and grease content increased significantly with increased pollution. Phyto-remediation of polluted soil led to significant oil and grease reduction in the order $\mathrm{Pp}<\mathrm{Cr}<\mathrm{Ll}$. Higher reduction at low pollution level could be attributed to the enhanced root formation and moisture content at such pollution level which decreased as pollution increased. The lower THC content of pre-pollution soil could be due to lack of exogenous source of hydrocarbon which however increased under post-polluted soil conditions. Phyto-application led to a drastic reduction in THC in polluted soil. Variation in THC of vegetated soil was in the order $\mathrm{Pp}<\mathrm{Cr}<\mathrm{Ll}$. Natural biodegradation is the major and ultimate mechanism for elimination of oil especially in aquatic environment which also seems to apply to soil environments. Related studies have shown that degradation of spilled oil is rapidly accelerated in vegetated soils than surrounding non-vegetated bulk soils $^{54}$.

Enhanced metabolism of organic pollutants in transgenic trees is associated with a faster uptake which can be explained by a steeper concentration gradient inside plant tissues ${ }^{12,49}$. Similarly, there are reports of a hybrid popular plant over-expressing enzyme capable of removing volatile hydrocarbons such as TCE, Vinyl chloride, carbon tetrachloride, chloroform and benzene from hydroponic solutions ${ }^{55}$. Several enzymes have been engineered using both rational and irrational approaches to drive the use of enzymes for enhanced activity, stability and expression in transgenic plants for phytoremediation $^{39,56}$.

\section{CONCLUSION}

The understanding of enzymatic processes involved in plant tolerance and detoxification of crude oil contaminated soil could provide new directions for manipulating plants with superior remediation potential. These enzymes can be tested for their activity in other environmental contaminants such as petroleum aliphatic and aromatic hydrocarbons. However, there was variation in enzyme expression levels among the species with C. retusa showing significantly better performance. Therefore, an engineered C. retusa can be an integral component of a bioremediation system that offers a novel approach for cleanup of crude oil polluted terrestrial environments.

\section{ACKNOWLEDGMENT}

The authors thank colleagues that helped with fieldwork and laboratory analyses over the study years. Our appreciation also goes to the blessed memory of the Late Prof. Dave Nosa Omakaro for his contributions.

\section{REFERENCES}

1. Greenberg, B.M., X.D. Hunag, Y. Gurska, K.E. Gerhardt, W. Wang and M.A., Lampi, 2006. Successful field tests of a multi-process phytoremediation system for decontamination of persistent petroleum and organic contaminants. Proceeding of the 29th Artic and Marine Oil Spill Program (AMOP) Seminar, Vol. 1, June 6-8, 2006, Vancouver, BC., Canada, pp: 389-400.

2. Gerhardt, K.E., X.D. Huang, B.R. Glick and B.M. Greenberg, 2009. Phytoremediation and rhizoremediation of organic soil contaminants: Potential and challenges. Plant Sci., 176: 20-30.

3. Van Aken, B., 2009. Transgenic plants for enhanced phytoremediation of toxic explosives. Curr. Opin. Biotechnol., 20: 231-236.

4. Glick, B.R., 2005. Modulation of plant ethylene levels by the bacterial enzyme ACC deaminase. FEMS Microbiol. Lett., 251: 1-7.

5. Huang, X.D., Y. El Alawi, J. Gurska, B.R. Glick and B.M. Greenberg, 2005. A multi-process phytoremediation system for decontamination of persistent Total Petroleum Hydrocarbons (TPHs) from soils. Microchemical. J., 81: 139-147. 
6. Salt, D.E., M. Blaylock, N.P.B.A. Kumar, V. Dushenkov, B.D. Ensley, I. Chet and I. Raskin, 1995. Phytoremediation: A novel strategy for the removal of toxic metals from the environment using plants. Nat. Biotechnol., 13: 468-474.

7. Edwin-Wosu, N.L. and P.D.S. Kinako, 2005. Phytoremediation innovative technology (Series 2): A short-term comparative analysis of enhanced biodegradation of crude oil in the soil by macrophytic nodulation. Global J. Environ. Sci., 4: 11-18.

8. Edwin-Wosu, N.L., 2005. Phytoremediation innovative technology (series 1): A short-term comparative analysis of remediation potential of macrophytic agro-forestry species in a water-habitat relationship of a crude oil polluted terrestrial habitat. Global J. Environ. Sci., 4: 135-138.

9. Parrish, Z.D., J.C. White, M. Isleyen, M.P. Gent and W. Iannucci-Berger et al., 2006. Accumulation of weathered Polycyclic Aromatic Hydrocarbons (PAHs) by plant and earthworm species. Chemosphere, 64: 609-618.

10. Aslund, M.L.W., B.A. Zeeb, A. Rutter and K.J. Reimer, 2007. In situ phytoextraction of Polychlorinated Biphenyl-(PCB) contaminated soil. Sci. Total Environ., 374: 1-12.

11. Edwin-Wosu, N.L. and P.D.S. Kinako, 2007. Phytoremediation innovative Technology (series 4): Carbon: Nitrogen $(\mathrm{C} / \mathrm{N})$ ratio as an index assessment of macrophytic remediation in a crude oil polluted terrestrial habitat. J. Nigeria Environ. Soc., 4: 95-99.

12. Aken, B.V., 2008. Transgenic plants for phytoremediation: Helping nature to clean up environmental pollution. Trends Biotechnol., 26: 225-227.

13. Edwin-Wosu, N.L., 2011. Phytoremediation: Soil $\mathrm{pH}$, moisture content, structure and textural assessment in a macrophytic treatment of crude oil simulated terrestrial habitat usingLeucaena leucocephala and Bauhinia monandra. J. Applied Sci. Environ. Manage., 15: 411-418.

14. Edwin-Wosu, N.L. and E. Albert, 2011. Total Hydrocarbon Content (TPH) as an index assessment of Macrophytic remediation process of a crude oil contaminated soil environment. J. Applied Sci. Environ. Manage., 14: 39-42.

15. Moore, M.T., J.H. Rodgers, S. Smith and C.M. Cooper, 2001. Mitigation of metolachlor-associated agricultural runoff using constructed wetlands in Mississippi, USA. Agric. Ecosyst. Environ., 84: 169-176.
16. Davis, L.C., 2006. Genetic engineering, ecosystem change and agriculture: An update. Biotehnol. Mol. Biol. Rev., 1: 87-102.

17. Doty, S.L., 2008. Enhancing phytoremediation through the use of transgenic plants and entrophytes. New Phytol., 1365: 5692-5693.

18. Singer, A., 2006. The Chemical Ecology of Pollutant Biodegradation. In: Phytoremediation and Rhizoremediation: Theoretical Background, Mackova, M., D. Dowling and K. Macek (Ed.). Springer, Germany, pp: 5-21.

19. Nepovim, A., R. Podlipna, P. Soudek, P. Schroder and T. Vanek, 2004. Effects of heavy metals and nitroaromatic compounds on horseradish glutathione S-transferase and peroxidase. Chemosphere, 57: 1007-1015.

20. Tayefi-Nasrabadi, H., G. Dehghan, B. Daeihassani, A. Movafegi and A. Samadi, 2013. Some biochemical properties of guaiacol peroxidases as modified by salt stress in leaves of salt-tolerant and salt-sensitive safflower (Carthamus tinctorius L. cv.) cultivars. Afr. J. Biotechnol., 10: 751-763.

21. Lavid, N., S. Amnon, L. Efraim and E. Tel-Or, 2001. Phenols and phenol oxidases are involved in cadmium accumulation in the water plants Nymphoides peltata (Menyanthaceae) and Nymphaeae (Nymphaeaceae). Planta, 214: 189-195.

22. Agostini, E., M.S. Coniglio, S.R. Milrad, H.A., Tigier and A.M. Giulietti, 2003. Phytoremediation of 2,4-dichlorophenol by Brassica napus hairy root cultures. Biotechnol. Applied Biochem., 37: 139-144.

23. Dwivedi, U.N., P. Singh, V.P. Pandey and A. Kumar, 2011. Structure-function relationship among bacterial, fungal and plant laccases. J. Mol. Catalysis B: Enzym., 68: 117-128.

24. Gramss, G., K.D. Voigt and B. Kirsche, 1999. Oxidoreductase enzymes liberated by plant roots and their effects on soil humic material. Chemosphere, 38: 1481-1494.

25. Cherian, S. and M.M. Oliveira, 2005. Transgenic plants in phytoremediation:? Recent advances and new possibilities. Environ. Sci. Technol., 39: 9377-9390.

26. Edwin-Wosu, N.L., 2011. Phytoremediation potential of some macrophytes on crude/waste oil polluted soils in the rainforest environment. $\mathrm{Ph}$. D. Thesis, University of Calabar.

27. Stewarte, A., H.M. Grimshaw and A.P. John, 1974. Chemical Analysis of Ecological Materials. Blackwell Scientific Publications, Oxford, Pages: 565. 
28. Song, H.G., X. Wang and R. Bartha, 1990. Bioremediation potential of terrestrial fuel spills. Applied Environ. Microbiol., 56: 652-656.

29. Akindele, S.O., 1996. Basic Experimental Design in Agricultural Research. Federal Universty of Technology Akure (FUTA) Press, Akure.

30. SAS., 2002. SAS for windows release 9.1. Statistical Analysis Systems Institute Incorporated, USA.

31. Nkang, A., 1990. Activities of peroxidases during seed development and germination in seeds of two contrasting rainforest species. Nigeria J. Bot., 3: 11-117.

32. Putter, J., 1974. Peroxidase... In: Methods of Enzymatic Analysis, Bergney, H.U. (Ed). Verlag Chemic, Meinheim, Germany, pp: 685- 690.

33. Kahn, V., 1983. Multiple effects of hydrogen peroxide on the activity of avocado polyphenol oxidase. Phytochemistry, 22: 2155-2159.

34. Jimenez, M. and F. Garcia-Carmora, 1995. pH-induced hysterics of latent broad bean polyphenol oxidase. Phytochemistry, 40: 373-376.

35. API., 1980. Manual on Disposal of Petroleum Wastes. American Petroleum Institute, Washington, DC.

36. Odu, C.T.I., L.C. Nwoboshi, S.O. Fagado and P.E. Awani, 1989. Post impact study of shell petroleum development company's nun River 8 delivery line oil spillage. Final Report, Shell Petroleum Development Company (SPDC), Nigeria.

37. Walkley, A. and C.A. Black, 1934. An examination of the Degtgareff method for determining soil organic matter and proposed modification of the chronic Acid titration method. Soil Sci., 37: 29-38.

38. Nelson, D.W. and L.E. Sommers, 1975. A rapid and accurate method for estimating organic carbon in soil. Proc. Indiana Acad. Sci., 84: 456-462.

39. Sakaki, T., 2012. Practical application of cytochrome P450. Biol. Pharm. Bull., 35: 844-849.

40. Aken, B.V. and S.L. Doty, 2009. Transgenic plants and associated bacteria for phytoremediation of chlorinated compounds. Biotechnol. Gen. Eng. Rev., 26: 43-64.

41. Morant, M., S. Bak, B.L. Muller and D. Werck-Reichhart, 2003. Plant cytochromes P450: Tools for pharmacology, plant protection and phytoremediation. Curr. Opin. Biotechnol., 14: 151-162.

42. Komives, T. and G. Gullner, 2005. Phase I xenobiotic metabolic systems in plants. Z. Naturforsch, 60: 179-185.
43. Goel, A., G. Kumar, G.F. Payne and S.K. Dube, 1997. Plant cell biodegradation of a xenobiotic nitrate ester, nitroglycerin. Nat. Biotechnol., 15: 174-177.

44. Hughes, J.B., J. Shanks, M. Vanderford, J. Lauritzen and R. Bhadra, 1996. Transformation of TNT by aquatic plants and plant tissue cultures. Environ. Sci. Technol., 31: 266-271.

45. Guo-Dong, W., L. Qian-Jin, L. Bin and C. Xiao-Ya, 2004. Ex planta phytoremediation of trichlorophenol and phenolic allelochemicals via an engineered secretory laccase. Nat. Biotechnol., 22: 893-897.

46. Edwin-Wosu, N.L., 2007. Phytoremediation (series 6). Botanical explanta-A-state-of-the-Art Technology in eco-environmental drive: The phytodegradation ecological role and challenges. J. Environ. Stud., 3: 97-110.

47. Adler, P.R., R. Anora, A. El-Ghaouth, D.M. Glenn and J.M. Solar, 1994. Bioremediation of phenolic compounds from water with plant root surface peroxidases. J. Environ. Qual., 23: 1113-1117.

48. Watkins, J.W., D.L. Sorensen and R.C. Sims, 1994. Volatilization and Mineralization of Naphthalene in Soil-Glass Microcosms. In: Bioremediation Through Rhizosphere Technology, Anderson, T.A. and J.R. Coats (Eds.). American Chemical Society, Washington, DC., pp: 123-131.

49. Dotty, S.L., T.Q. Shang, A.M. Willson, J. Tangen, A.D. Westergreen, L.A. Newman, S.E. Strand and M.P. Gordon, 2000. Enhanced metabolism of halogenated hydrocarbon in transgenic plants containing mammalian cytochrome. Proceeding of the 2nd International Conference on Remediation of Chlorinated and Recalcitrant Compounds, May 22-25, 2000, National Academy of Science, USA., pp: 6287-6291.

50. Li, L. and J.C. Steffens, 2002. Overexpression of polyphenol oxidase in transgenic tomato plants results in enhanced bacterial disease resistance. Planta, 215: 239-247.

51. Ranocha, P., M. Chabannes, S. Chamayou, S. Danoun, A. Jauneau, A.M. Boudet and D. Goffner, 2002. Laccase down-regulation causes alterations in phenolic metabolism and cell wall structure in poplar. Plant Physiol., 129: 145-155.

52. Duran, N., M.A. Rosa, A. D'Annibale and L. Gianfreda, 2002. Applications of laccases and tyrosinases (phenoloxidases) immobilized on different supports: A review. Enzyme Microb. Tech., 31: 907-931. 
53. Bais, H.P., R. Vepachedu, S. Gilroy, R.M. Callaway and J.M. Vivanco, 2003. Allelopathy and exotic plant invasion: From molecules and genes to species interactions. Science, 301: 1377-1380.

54. Banks, M.K., R.S. Govindaraju, A.P. Schwab and P. Kulakow, 2000. Field Demonstration. In: Phytoremediation of Hydrocarbon Contaminated Soil, Florenza, S., C.L. Oubre and C.H. Ward (Eds.). Lewis Publishers, Baton Rouge, pp: 3-88.
55. Doty, S.L., T.Q. Shang, A.M. Wilson, J. Tangen and A.D. Westergreen et al., 2000. Enhanced metabolism of halogenated hydrocarbons in transgenic plants containing mammalian cytochrome P450 2 E1. Proc. Nat. Acad. Sci., 97: 6287-6291.

56. Bernhardt, R., 2006. Cytochromes P450 as versatile biocatalysts. J. Biotechnol., 124: 128-145. 